\title{
THE JOURNAL OF NeUrology AND Psychiatry
}

\author{
FOUNDED BY S. A. K. WILSON
}

Vol 4 [New Series]

JULY-OCTOBER, 1941

Nos. $3 \& 4$.

\section{SULPHANILAMIDE AND SULPHAPYRIDINE IN EXPERIMENTAL CEREBRAL WOUNDS}

\author{
BY
}

\author{
E. H. BOTTERELL, E. A. CARMiChAEL, and W. V. CONE \\ (Received 16TH August, 1941)
}

THE local use of sulphanilamide and sulphapyridine in wounds is proving valuable both by preventing infection and in controlling established infection. These drugs may be expected to have the same bacteriolytic and bacteriostatic effects in cerebral wounds as in wounds of other tissues, for the reaction of the brain to wounding and infection is basically similar. The reaction of other tissues to these drugs has not prevented their use locally in wounds. Healing has been shown to be delayed slightly but not significantly. Acute inflammatory reaction in response to the presence of sulphanilamide or sulphapyridine has been transitory in most tissues even though large amounts of drug have been applied. In cerebral wounds the inevitable local reaction to any foreign material and the potential remote toxic effects on nerve cells, neuroglia, and myelin may make it undesirable to implant sulphonamides. The purpose of these experiments was to determine whether such undesirable local and remote reactions followed the introduction of large amounts of sulphanilamide or sulphapyridine into cerebral wounds, and if they were sufficiently marked to contra-indicate their use. Observations were also made on the time taken for the drugs to disappear from the wounds, the levels of each drug reached in the blood, and the reaction of the tissue to these two drugs.

\section{Experimental procedure}

Defects were made in the cortex and white matter of one or other cerebral hemisphere in a series of thirty cats. Twenty-four experiments were satisfactory for our purpose. Following the incision of the pia mater, cerebral tissue was crudely excised by blunt dissection. Careful and repeated wiping out of the 
wound with gauze produced a cavity large enough to contain approximately barely $500 \mathrm{mgm}$. of the drug. When it was not large enough to hold $500 \mathrm{mgm}$. of drug it was spilled over into the subdural space, covering the leptomeninges near the excision. The defects measured $1-1 \frac{1}{2} \mathrm{~cm}$. in diameter. In some of the animals openings were made into the ventricles while in others the excisions were superficial to the ventricle. The dura was not sutured but the temporal muscle, when replaced, closed the dural opening and small bone defect. The operations were carried out under either intravenous or intraperitoneal nembutal anæsthesia.

Certain technical details should be mentioned, for they may bear on our conclusions. The heads were shaved, scrubbed with soap and water, and painted with metaphen in alcohol and acetone. Sterile towels were used as drapes. The surgeon scrubbed for ten minutes, soaked his hands for about a minute in 1 in 1,000 mercuric potassium iodide, but wore no gloves, cap, or mask. The chemically pure, finely-powdered sulphanilamide and sulphapyridine had each been put up in sealed glass ampoules containing $500 \mathrm{mgm}$. The outside of the ampoules was sterilized by boiling for ten minutes. Sometimes, when the ampoules were broken, small pieces of glass fell into the crystals of drug and, unrecognized, were put into the wound with the drug.

It was often observed that hæmorrhage ceased when a wound cavity was heavily coated with sulphapyridine and light pressure applied. When sulphanilamide was used the same effect was not obtained. This may be due to the greater solubility of sulphanilamide. Again, sulphapyridine forced into venous channels of the cat's skull and held there frequently stopped bleeding effectively though less promptly than Horsley's bone-wax. We accordingly concluded that sulphapyridine in stopping bleeding probably acted only as a mechanical agent.

The general health of these animals was excellent once they had recovered from the immediate effects of the anæsthetic and operation. In no instance was any disability attributed to the local use of either sulphapyridine or sulphanilamide.

\section{Results}

Time required for relatively large amounts of drug to disappear from cerebral wounds

\section{SulPhaniLAMIDE}

Brain defects were made superficial to the ventricle in eight cats and into the lateral ventricle in three cats. For reasons to be discussed later these eleven experiments will be considered as one group. The durations of the experiments were as follows : less than 24 hours, 2 days, 6, 18, 18, 27, 36, $46,90,93$, and 95 days. One animal died during the first day from intracerebral and intraventricular hæmorrhage. Crystals of drug mixed with blood filled the brain defect. A second animal, killed after two days, had never recovered consciousness as a result of hæmorrhage into the drug-filled defect and surrounding brain. Masses of crystals were present. In the third cat a 
spongy mass of crystals mixed with red blood cells filled the brain defect on the sixth day. Two animals were killed on the eighteenth day after operation, and in these no drug could be seen in the brain wounds with the unaided eye. In both animals a small amount of yellow pigmented sludge was present deep to the dural scar. Microscopical studies showed a few spaces at the site of cerebral injury of one of these eighteen-day cats, indicating that crystals of sulphanilamide in free or acetylated form had been dissolved out. The reason for this opinion will be discussed in a later section.

No drug was found macroscopically in the brains of any of the six animals

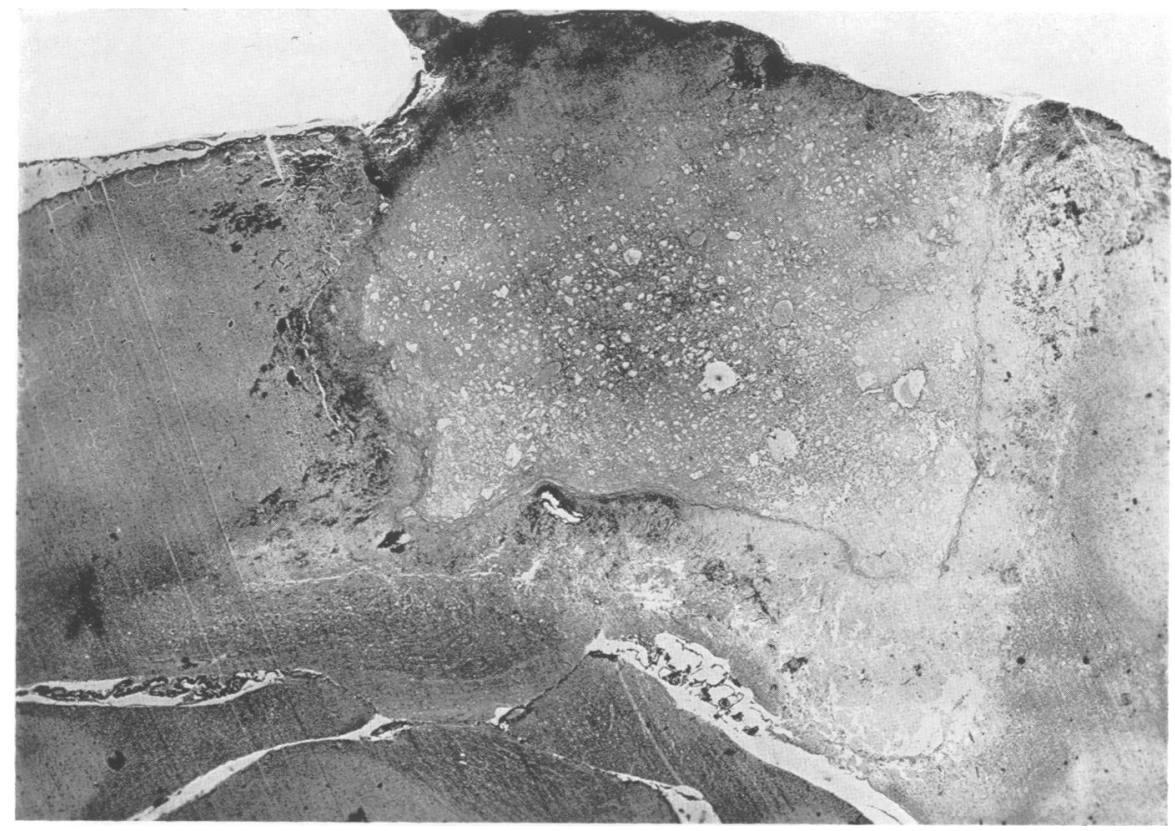

Fig. 1.-The cerebral defect was still filled with crystals of sulphanilamide 6 days following operation.

killed $27,36,46,90,93$, and 95 days after operation, but microscopically, spaces which probably contained sulphanilamide crystals were found in the scar of the 27-day animal. This was the longest period after operation that any microscopical evidence was found suggesting the presence of sulphanilamide.

\section{SULPHAPYRIDINE}

In eight animals sulphapyridine was placed in wounds superficial to the ventricle, while in five animals the ventricle was opened. These thirteen animals will also be considered as a single group. The duration of the various experiments was $2,8,14,16,30,44,44,51,58,61,63,88$, and 108 days. Large quantities of crystals were seen in the cerebral wounds of $2,8,14,16$, and 30-day experiments. Beyond the 30-day period the drug was found in but one cerebral scar and that was as an encysted island of crystals measuring $2 \times 3 \times 8 \mathrm{~mm}$. in an animal killed after 51 days. It is noteworthy that neither of the 44-day 
experimental wounds contained any crystals. When the drug was not recognized with the unaided eye it was not found microscopically.

In considering the time taken for sulphanilamide or sulphapyridine to disappear from brain wounds, several reasons impelled us to group all the experi-

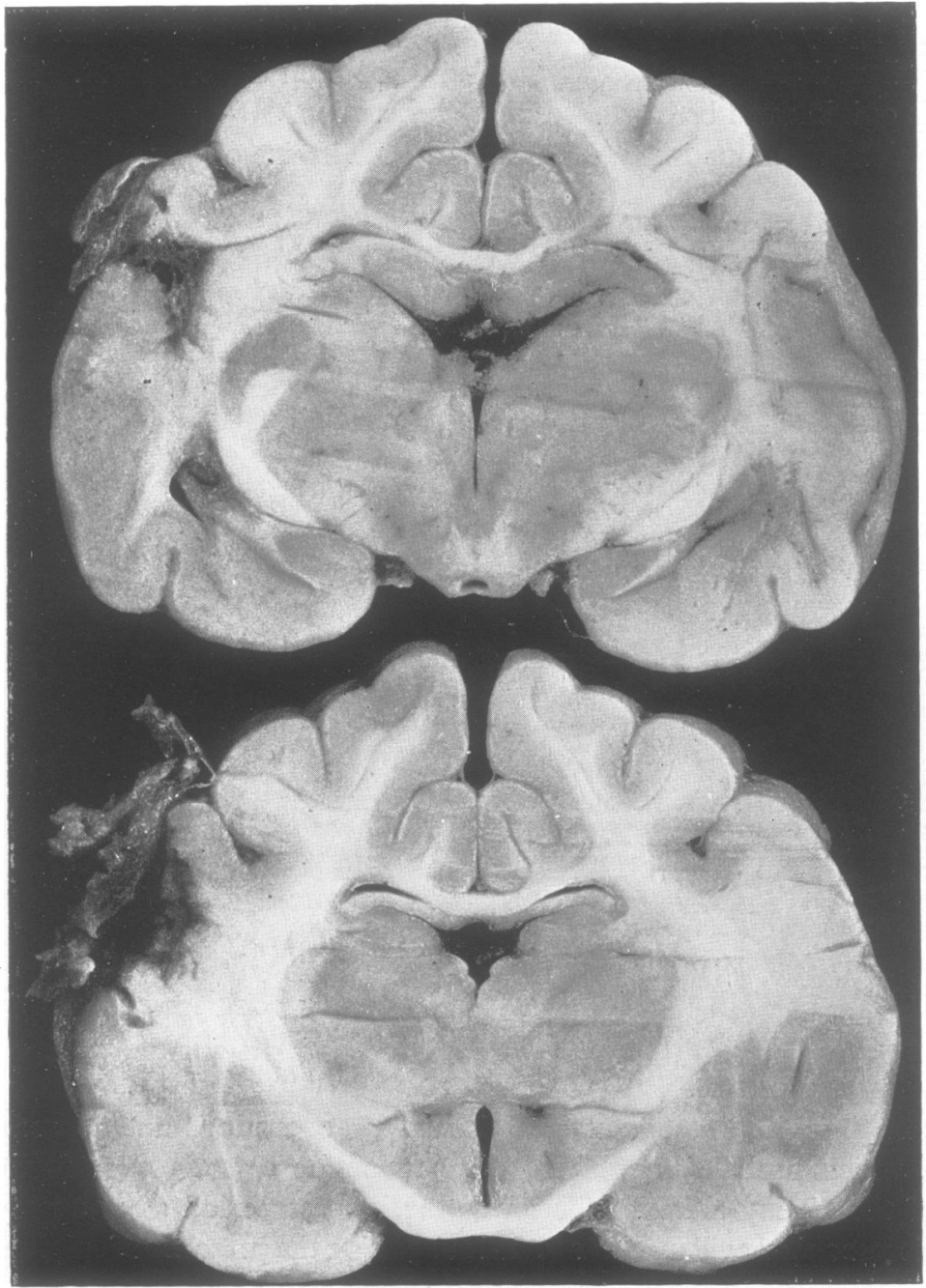

Fig. 2.-18 days following the operation and implantation of sulphanilamide no gross drug was seen. A cystic pigmented scar was present with a thin layer of amorphous pigment immediately deep to the dural scar. Microscopically spaces were found which probably contained crystals.

ments together irrespective of whether or not there was an opening into the ventricle. In some instances the ventricle was widely opened, while in other operations ventricular fluid seeping into the wound was the only evidence of an opening. The length of time during which ventricular fluid washed away the drug, and in what quantity, would in part depend on the size of the opening 


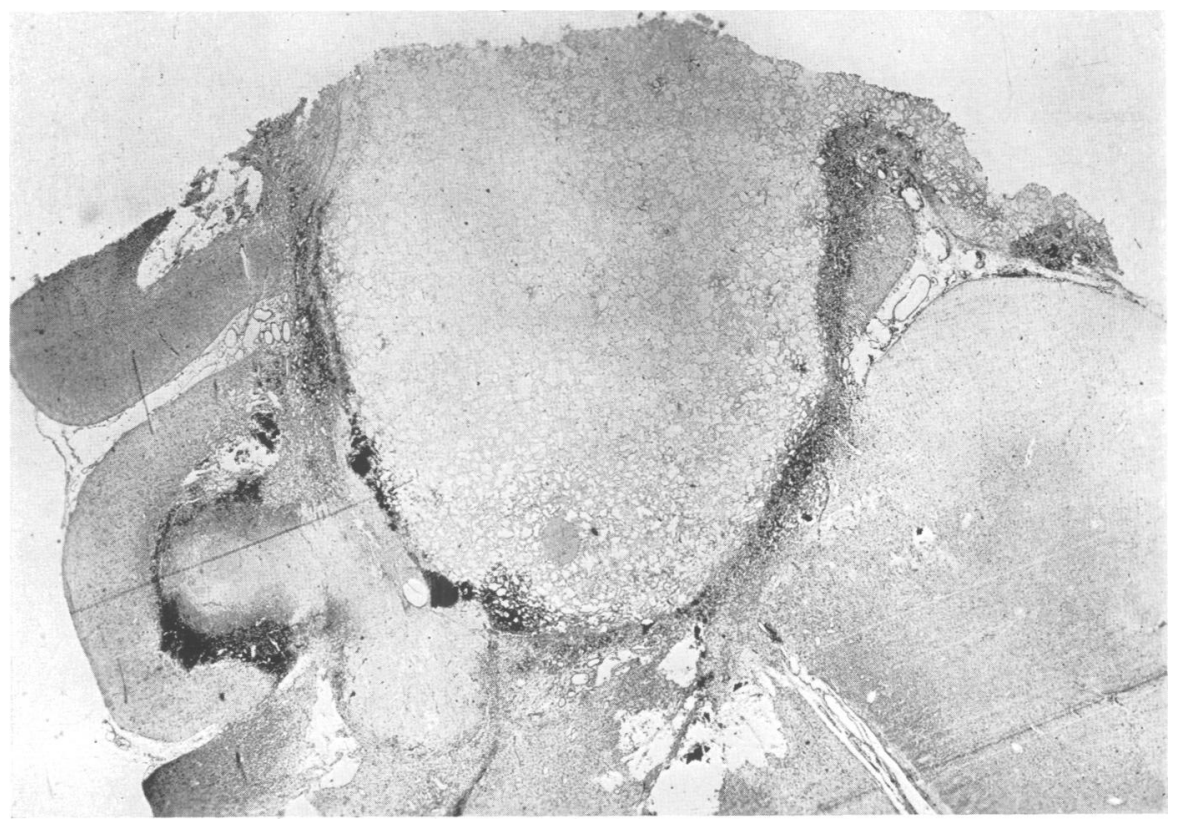

Fig. 3.-14 days after operation sulphapyridine was found completely filling the cerebral defect and overflowing into the sub-dural space. The encapsulation of the drug is well shown.

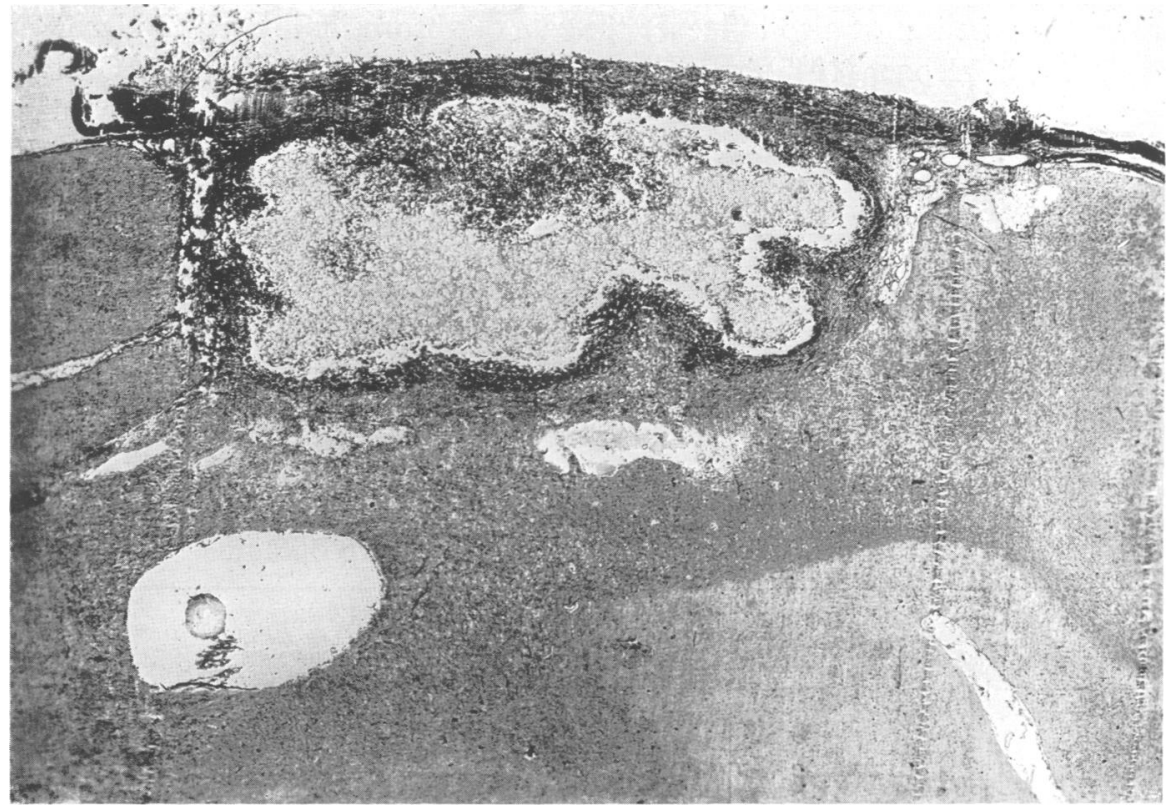

Fig. 4.-30 days fcllowing implantation of sulphapyridine, a large amount of crystalline drug was still present. The encapsulation was heavier, and finger-like collections of phagocytes projected from the periphery into the crystalline mass of drug. 


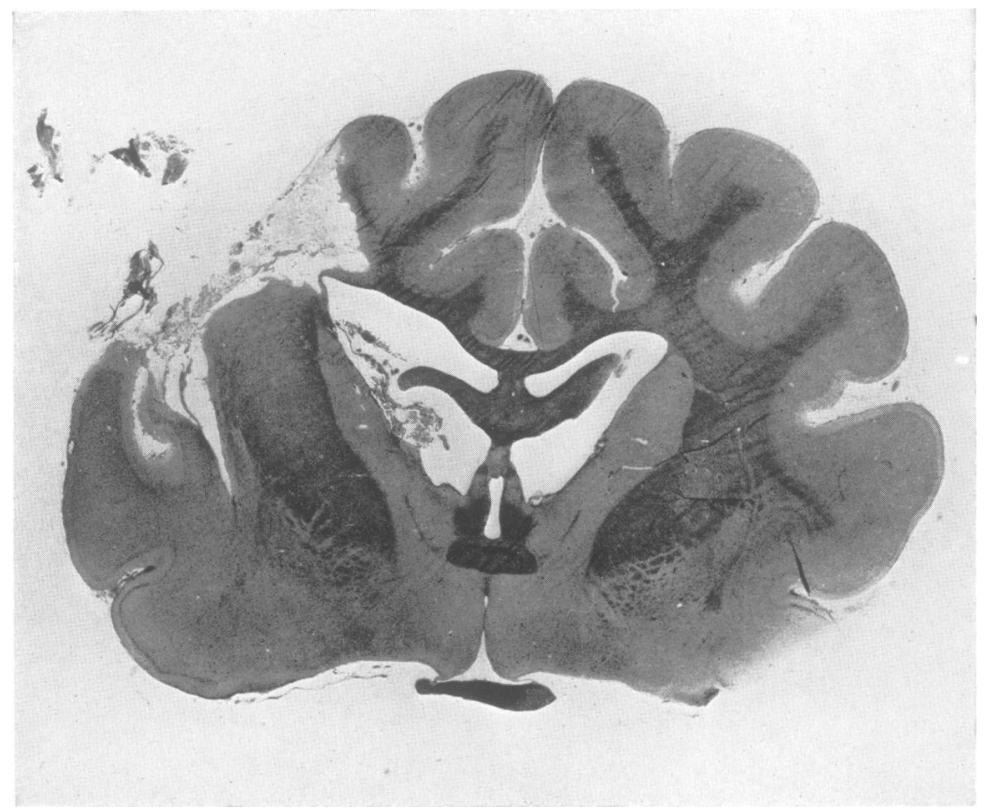

Fig. 5.-108 days after implanting sulphapyridine no drug was present. The excision extended down to the ependymal lining of the lateral ventricle. The large defect was filled with a loose spongy neuroglia connective tissue matrix. The lateral ventricle on the side of the wound was dilated.

into the ventricle and how long the opening remained patent. The solubility of the drug used must also influence the rate of absorption by ventricular fluid Russell and Falconer (1940) quoted a personal communication from J. O'Brien indicating that $1,250 \mathrm{mgm}$. of sulphanilamide or $85 \mathrm{mgm}$. of sulphapyridine will dissolve in 100 c.c. of normal C.S.F. incubated at $35^{\circ}$ C. for 14 hours. In our experiments the drug became encapsulated after some days, regardless of an opening into the ventricle, thus minimizing the passage of the drug into ventricular fluid. For these reasons, it appears unnecessary to divide the experiments into two groups : namely, those with open and those with closed ventricles.

\section{Absorption of Sulphapyridine and Sulphanilamide}

\section{SULPHAPYRIDINE}

Blood levels were estimated daily in a group of animals during the 3-day period following operation. The following results were obtained :

\begin{tabular}{|c|c|c|c|c|c|}
\hline \multicolumn{2}{|c|}{$\begin{array}{l}24 \text { HOURS } \\
\text { mgm. per cent. }\end{array}$} & \multicolumn{2}{|c|}{$\begin{array}{c}2 \text { DAYS } \\
\text { mgm. per cent. }\end{array}$} & \multicolumn{2}{|c|}{$\begin{array}{c}3 \text { DAYS } \\
\text { mgm. per cent. }\end{array}$} \\
\hline $\begin{array}{l}\text { Free } \\
0 \cdot 1 \\
0.74 \\
1 \cdot 2 \\
1 \cdot 3 \\
1 \cdot 15\end{array}$ & $\begin{array}{c}\text { Total } \\
1 \cdot 1 \\
\text { not done } \\
1.2 \\
1.4 \\
1.5\end{array}$ & $\begin{array}{l}\text { Free } \\
0.7 \\
1.2 \\
1.3 \\
1.0 \\
0.59 \\
1.78\end{array}$ & $\begin{array}{c}\text { Total } \\
1 \cdot 1 \\
1.4 \\
1.6 \\
1 \cdot 1 \\
\text { not done } \\
2.0\end{array}$ & $\begin{array}{l}\text { Free } \\
0.71 \\
0.5 \\
-\overline{0.65} \\
0.9\end{array}$ & $\begin{array}{c}\text { Total } \\
\text { not done } \\
\text { ", } \\
", \\
",\end{array}$ \\
\hline
\end{tabular}


These levels were so low that only occasional further blood specimens were taken during the periods of survival in addition to an immediate ante-mortem one. Between the 4 th and 30 th post-operative days 15 blood estimations ranged from "very low" to $0.67 \mathrm{mgm}$. per cent. free sulphapyridine. In two instances total sulphapyridine was estimated as well as free ; 11 days after operation the figures per cent. free and total respectively were 0.3 and $0.78 \mathrm{mgm}$., and at 30 days 0.25 and $0.3 \mathrm{mgm}$. Between 11 and 30 days after operation, six specimens of urine were tested for the presence of the drug. The following table indicates the amounts obtained.

\begin{tabular}{|c|c|c|c|c|}
\hline \multirow[t]{2}{*}{ DAYS AFTER OPERATION } & \multicolumn{2}{|c|}{$\begin{array}{l}\text { BLOOD SULPHAPYRIDINE } \\
\text { mgm. per cent. }\end{array}$} & \multicolumn{2}{|c|}{$\begin{array}{l}\text { URINE SULPHAPYRIDINE } \\
\text { mgm. per cent. }\end{array}$} \\
\hline & $\begin{array}{c}\text { Free } \\
0.4 \\
0.2 \\
- \\
\text { v. low } \\
0 \cdot 27 \\
0.25\end{array}$ & $\begin{array}{l}\text { Total } \\
\text { not estimated } \\
" \quad \text { - } \\
\text { not estimated } \\
\text { " } 0.3 "\end{array}$ & $\begin{array}{l}\text { Free } \\
19 \\
14 \cdot 3 \\
14 \cdot 5 \\
10 \cdot 0 \\
8 \cdot 35 \\
0 \cdot 5\end{array}$ & 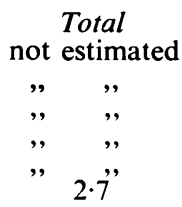 \\
\hline
\end{tabular}

No drug was present in the urine of two cats on the 88th and 108th days after operation. Of five animals killed $41,44,51,58$, and 63 days after operation, no drug was found in the blood at the time of death. Cerebrospinal fluid was tested, prior to sacrifice, from another 44-day animal as well as from the 44, 58, and 63-day animals and found to contain no drug. It was noteworthy that there was an island of drug $2 \times 3 \times 8 \mathrm{~mm}$. in the cerebral scar of the 51-day animal. The urine of this animal was not tested at the time of death.

\section{SulPHANILAMIDE}

In two cats the blood levels of free and total substances after 24 hours were 0.6-0.67 mgm. per cent. and 0.55-0.61 mgm. per cent. respectively. In another animal a reading of 0.81-1.0 mgm. per cent. was obtained after 6 days. Seven further specimens from the series of animals were obtained ranging from 11 to 36 days after operation. Drug was found, $0 \cdot 2-0.22 \mathrm{mgm}$. per cent. in only one blood 22 days after operation. It will be recalled that no gross drug was found in the brain of any animal killed after the 6th day, although microscopical examination indicated spaces which probably contained crystals of sulphanilamide in one of two 18-day animals and in the 27-day animal.

\section{Macroscopical findings}

The brains were fixed in situ by intracarotid injection with either Cajal's ammonium bromide or 4 per cent. formalin (10 c.c. of 40 per cent. formalin per 100 c.c. tap water). In those animals in which clotting prevented fixation by this method, the brains were removed and suspended in the fixative to harden before sectioning. The dura and temporal muscle over the brain wound was always left attached to the brain during the fixing process. 
There was no macroscopical evidence, regardless of the length of postoperative survival, that sulphanilamide or sulphapyridine caused either œdema of the injured hemisphere or of the other hemisphere. This was evident in parallel coronal sections, which disclosed no asymmetry of the hemispheres. The width and sharpness of outline of the grey matter were identical on the two sides when comparable areas were measured. The corona radiata were symmetrical. No herniation of the brain took place, though the dura had been left open. The leptomeninges away from the wounds appeared to be normal. In all experiments, regardless of whether or not the ventricle had been opened, the ependyma of the lateral third and fourth ventricles was smooth and glistening. The aqueduct of Sylvius was always patent.

Examination of the brain wounds of animal which did not recover from the anæsthetic or did not regain consciousness within 24 hours of operation showed that the operative removal of cortex had lacerated grey matter and caused irregular pockets and areas of hæmorrhage of varying size in the white matter some considerable distance from the wound. The satisfactory wounds were comparable to the wounds left in human beings after debridement of serious lacerated wounds of the brain.

In experiments terminated as early as the 8th day a delicate capsule was recognized around the implanted drug. Thick capsules developed about sulphapyridine in the later stages. Around sulphanilamide the same connective tissue encapsulation occurred, but never reached similar thicknesses to those around implanted sulphapyridine. The difference in this degree of encapsulation may be explicable on the different solubilities of the two substances. In the later stages with complete disappearance of both drugs the capsule became less prominent and the region of the wound appeared as a loose-meshed spongy yellowish tissue, usually cystic but sometimes containing pigments. The ventricle adjacent to the wound was found enlarged, especially when the drug had disappeared and the inflammatory reaction had subsided. Bone marrow, kidneys, ureters, and the bladder showed no evidence of having been affected by the drugs in any of the experimental animals.

\section{Microscopical findings}

A composite description of the microscopical findings will be given rather than a detailed report of the findings in each experiment. The earliest reactions about either drug was an outpouring of polymorphonuclear leucocytes, which formed a heavy though uneven mantle around the crystals and even penetrated for a short distance into the mass. Phagocytic cells made their appearance at an early stage and formed a zone outside the polymorphonuclear cells. In this zone lymphocytes appeared, fibroblasts differentiated, and reticulum was laid down.

As the polymorphonuclear leucocytic reaction became less intense the cells degenerated and fragmented nuclear chromatin was scattered at the border zone between the drug and the phagocytes. Phagocytes increased in number and insinuated themselves between the crystals at the margins of the 
drug. At a later stage multinucleated phagocytes (giant cells) became numerous in this zone about the crystals. The way in which the phagocytes next to the crystals elongated and oriented themselves at right angles to the developing capsule as they invaded the crystals was striking. At later periods plasma cells were found mixed with the lymphocytes, and in the brain tissue adjacent to the outer layer of this reaction phagocytes were present.

As the drug disappeared the inflammatory reaction subsided and giant cells became less numerous. When the sulphanilamide crystals disappeared a loose meshwork of astrocytes and connective tissue surrounded small cysts containing some phagocytes. In this meshwork and around the blood vessels there were a few lymphocytes and plasma cells. At this stage the giant cells had disappeared.

The scars in the longest experiments contained much less connective tissue than had been anticipated, in view of the intensity of the inflammatory reaction at certain periods and its duration. The well-formed connective tissue capsule seen at the intermediate periods when the drug had not been completely absorbed entirely disappeared. The amount of collagenous connective tissue was greater in the wounds filled with sulphapyridine.

In a microscopical study it was found that the microglia underwent transition to the phagocytic form near the drug and altered for a short distance from the wounds in the white matter to rod forms and phagocytes. Astrocytes in the immediate vicinity of the wound underwent the classical changes, showing first hypertrophy and then increase of neuroglia fibres. Away from the wound the astrocytes were normal. No reaction of the astrocytes was observed in the normal hemisphere. Oligodendroglia was more readily stained than usual in the hemisphere on the side of the operation. No other definite alteration in it was made out. Normal cells were present quite close to the area of wounding. Neurofibril and nerve cell stains, as also stains for myelin, disclosed no abnormality away from the wound or in the opposite hemisphere.

While the macroscopical examination had shown no changes in the leptomeninges away from the traumatized area polymorphonuclear leucocytes and phagocytes were found microscopically in the subarachnoid space in the shorter experiments and lymphocytes and phagocytes in the later ones. This reaction was confined to the subarachnoid space in the neighbourhood of the wound. No other constant abnormality was made out.

It was interesting that in both experiments in which a wide opening had been made into the ventricle the drug nevertheless was found to be encapsulated. When a transventricular wound was made encapsulation still took place with partial blocking of the ventricle. As absorption and healing occurred transventricular septa remained to distort the ventricular outline.

Qualitatively the reaction to sulphanilamide and sulphapyridine was the same. Quantitatively there was a difference. More polymorphonuclear leucocytes surrounded sulphanilamide than sulphapyridine crystals in the early stages after implantation. With sulphapyridine, which took approximately twice as long to absorb as sulphanilamide, the inflammatory reaction was prolonged and the connective tissue encapsulation was thicker. However, in the 
longest experiments the scarring was no more intense in the wounds treated with sulphapyridine than it was in those filled with sulphanilamide. For example, in wounds of 90 and 108 days much of the mesodermal reaction had disappeared and it was impossible to determine by study of sections which drug had been implanted.

No microscopical abnormalities due to the drugs were found in the bone marrow or kidneys of any of the experimental animals.

\section{Comment}

The cerebral defect produced at operation was large in proportion to the size of the cat's brain, and because of the operative technique used the lesions simulated in many ways a deep wound in the human brain following an incomplete debridement. In this series of animals $500 \mathrm{mgm}$. of either sulphanilamide or sulphapyridine disappeared completely from wounds in the brain. It is estimated that a comparable quantity of these drugs applied to an injury of the brain of man would amount to from 25 to $50 \mathrm{gm}$. This comparison may serve to demonstrate the severity of the test to which local application of sulphonamides was put. Our experiments indicated that the intensity and duration of the inflammatory reaction depended upon the quantity of drug used, its solubility, and the length of time it remained in the wound. Though large amounts of drug were implanted, if the animals survived as long again, or even longer, than had been shown requisite for these drugs to disappear, there was but little ultimate connective tissue scarring. At most a loose-meshed mixture of neuroglial cells and a small amount of connective tissue surrounded small cysts containing phagocytes. This type of scar occurred with both sulphapyridine and sulphanilamide. Some of the late scars were as satisfactory as those following experimental wounds carried out with extreme care and without implantation of any absorbable foreign bodies.

Under the circumstances of these experiments using about $500 \mathrm{mgm}$. of drug, sulphanilamide disappeared completely in from 18 to 36 days and sulphapyridine from 44 to 58 days. Russell and Falconer (1940) found that a pellet of $1 \mathrm{mgm}$. of sulphapyridine injected hypodermically into the cortex of a rabbit's brain disappeared within four days and $1 \mathrm{mgm}$. of sulphonamide within twentyfour hours. They also observed a foreign body reaction characterized by the presence of phagocytic foam cells and multinucleated giant cells. Hurteau (1941) inserted about $100 \mathrm{mgm}$. of drug into wounds in the brains of cats and then used the chemical method of Maher and Camp (1938) to test for the presence of sulphonamide in the cerebral substance. Sulphapyridine was not detected after 34 days, sulphathiazol after 17 days, and sulphanilamide after 11 days. The relation between the quantity of drug inserted and time required for the drug to be absorbed is apparent if the results of our experiments are contrasted with those obtained by Russell and Falconer and by Hurteau.

Final conclusions have not yet been reached as to how valuable sulphanilamide and sulphapyridine are as bacteriostatic and bacteriolytic agents when applied locally. Experimental and clinical data are accumulating which 
suggest that their in vitro action is duplicated in wounds, high concentrations of sulphanilamide having significant bacteriostatic and bacteriolytic effects on a variety of organisms. In our experiments sulphanilamide was absorbed much more quickly from wounds of the brain than sulphapyridine, and the resultant inflammatory and foreign body giant cell reactions were therefore so much shorter that it is probably the drug of choice for local application in wounds of the brain. It can be more generously applied than sulphapyridine or sulphathiazol.

Consideration of the results of these experiments, in relation to the problems of treatment of injuries to the brain of man, indicates that the local foreign body reaction does not contra-indicate the application of sulphanilamide or sulphapyridine. Regardless of which sulphonamide is applied to a cerebral wound locally, excessive quantities of drug should not be used, and in all probability a thin layer coating the walls of the wound should be considered sufficient if sulphapyridine is used.

Local implantation does not provide a depot from which absorption will take place and give adequate blood levels. The low levels of both sulphanilamide and sulphapyridine reached in the blood, a maximum of $0.67 \mathrm{mgm}$. per cent. and $1.78 \mathrm{mgm}$. per cent. respectively of the free drugs, are not accepted as being of therapeutic value. No estimations were possible of the drug levels attained by either sulphanilamide or sulphapyridine in the region of these cerebral wounds.

No attempt has been made in this series of experiments to assess the therapeutic value of using sulphanilamide or sulphapyridine, but it is of interest that there was no instance of deep infection or meningitis among the thirty cats operated on. The brain wounds were purposely of a lacerated type, and it is not uncommon in such a series of laboratory experiments to have an occasional infection of a cerebral wound ; it is therefore all the more remarkable that no wound was infected in this series.

One very practical point in surgical technique comes from this work. Sulphapyridine crystals may be used effectively to control bleeding from smalland medium-sized venous channels in bone by blocking the opening.

\section{Summary}

After $500 \mathrm{mgm}$. of pure sulphanilamide were placed in brain defects, crystals were found up to the 6 th day but not on the 18 th day post-operative. Microscopically drug was probably still present on the 27 th day but not on the 36 th day after operation.

It required from 44 to 58 days for an equal amount of sulphapyridine to be completely absorbed.

No impairment in the general health of the animals was attributed to the local use of sulphanilamide or sulphapyridine. No damage to liver, bone marrow, kidneys, or bladder was discovered.

The highest levels of either sulphanilamide or sulphapyridine found in the 
blood, resulting from absorption of drug implanted in the cerebral wounds, were never sufficient to be of therapeutic value.

Both drugs act as foreign bodies as long as they persist in cerebral wounds. The tissue reaction is a local one and the drugs are eventually encapsulated. When absorption is complete the inflammatory reaction subsides. The quality of the local reaction to the two drugs is the same. Rather more polymorphonuclear leucocytes surround sulphanilamide than sulphapyridine in the early stages. Sulphapyridine takes approximately twice as long to disappear from a brain wound as does sulphanilamide, and there occurs a heavier connective tissue encapsulation.

No undesirable side effects were observed on nerve cells, neuroglia, or myelin at a distance from the drugs. The reaction remained as a local one.

In the longest experiments the cerebral scars did not seem more extensive or more active than scars following wounds studied in previous series of experiments and uncomplicated by the local use of sulphonamides.

As a result of these experiments we have not hesitated to use sulphonamides in potentially infected or infected wounds of the human brain, but we have used them circumspectly. We shall continue to use them guardedly even when their local bacteriostatic and bacteriolytic action is proven beyond doubt, for they do act also as foreign bodies.

This work was carried out on behalf of the Medical Research Council at the Research Unit of the National Hospital, Queen Square, London, W.C.1. Messrs. May and Baker, Ltd., kindly provided the drugs used throughout the investigation.

\section{REFERENCES}

Russsill, D. S., and Falconer, M. A. (1940). Lancet, 2, 100.

Hurteau, E. F. (1941). Canad. Med. Ass. J., 44, 352.

Maher, F. T., and Camp, W. J. R. (1938-39). J. Lab. clin. Med., 24, 1198.

\section{ILLUSTRATIONS}

The illustrations were chosen to demonstrate the relatively early disappearance of 500 mgm. of sulphanilamide from a wound in the brain in contrast to the later disappearance of $500 \mathrm{mgm}$. of sulphapyridine. The oldest wound, studied 108 days following operation, is shown because it is typical of the extent of the excisions carried out and the amount of the scarring present at this stage. 